\title{
Tanggung Jawab Direksi Perseroan Terbatas yang Dinyatakan Pailit
}

\author{
Machsun Thabrani
}

\begin{abstract}
This article is intended to discuss about the responsibility's director of limited company that is bankcrutized. In the paragraph 90 the Acts number 1, 1995 about Company Limited manage that the director can be asked for his responsibility personally when the company limited is stated to be bankrupt. But the director of company limited must responsible not by the law personally if the element of mistake is as the base of responsibility for director as described at paragraph 85 article (1) and (2) the Acts number 1, 1995 about unfulfilled Company Limited.
\end{abstract}

\section{Pendahuluan}

. Undang-Undang Nomor 1 Tahun 1995 tentang Perseroan Terbatas secara rinci mengatur organ perseroan terbatas yang terdiri dari Rapat Umum Pemegang Saham, Direksi, dan Komisaris serta tanggung jawab dari masing-masing organ Perseroan Terbatas tersebut. Direksi merupakan organ perseroan terbatas yang bertanggungjawab penuh terhadap pengurusan perseroan terbatas untuk kepentingan dan tujuan perseroan serta mewakili perseroan baik di dalam maupun di luar pengadilan.

Apabila direksi tidak menjalankan tugas untuk kepentingan dan usaha perseroan terbatas dengan baik dan rasa tanggung jawab, maka direksi dapat dimintakan pertanggungjawaban sampai dengan harta pribadinya. Tanggung jawab sampai ke harta pribadi dilakukan apabila direkși Perseroan Terbatas benar-benar terbukti telah melakukan kesalahan yang menyebabkan perseroan terbatas menderita kerugian secara signifikan. Apa dasar pertanggungjawaban direksi perseroan terbatas dalam UndangUndang Nomor 1 Tahun 1995 tentang Perseroan Terbatas? Bagaimana tanggung jawab direksi apabila perseroan terbatas yang dipimpinnya dinyatakan pailit?

\section{Perseroan Terbatas sebagai Badan Hukum}

Perseroan Terbatas merupakan badan hukum. Ketentuan ini diatur dalam Pasal 1 angka 2 Undang-Undang Nomor 1 Tahun 1995 tentang Perseroan Terbatas yang menyatakan: 
"Perseroan Terbatas selanjutnya disebut perseroan adalah badan hukum yang didirikan berdasarkan perjanjian, melakukan kegiatan usaha dengan modal dasar yang seluruhnya terbagi dalam saham, dan memenuhi persyaratan yang ditetapkan dalam undang-undang ini.sertaperaturan pelaksananya."

- Ketentuan tersebut dengan tegas menyatakan bahwa perseroan terbatas adalah badan hukum. Badan hukum merupakan subjek hukum; selain orang dewasa. Subjek hukum adalah sesuatu yang dapat atau cakap melakukan perbuatan hukum atau melakukan tindakan perdata atau membuat perikatan. ${ }^{1}$

Pasal 1329 Kitab Undang-Undang Hukum Perdata merupakan dasar hukum bahwa orang pribadi adalah subjek hukum, sedangkan Pasal 1654 Kitab Undang-Undang Hukum Perdata merupakan dasar hukum bagi badan apa saja yang merupakan badan hukum. ${ }^{2}$ Pasal 1654 Kitab Undang-Undang Hukum Perdata antara lain mengatur bahwa semua perkumpulan yang sah 'adalah, seperti halnya dengan orang-orang, berkuasa melakukan tindakan-tindakan perdata.

Kitab Undang-Undang Hukum Perdata tidak menerangkan siapa sajá yang termasuk dalam badan hukum yang sah, namun menerangkan perkumpulan atau badan hukum terdiri dari: ${ }^{3}$ Pertama, Perseorangan sejati atau badan usaha. Kedua, Perhimpunan orang atau badan organisasi atau sosial atau perkumpulan atau badan hukum dalam arti sempit.

Pasal 1653 Kitab Undang-Undang. Hukum ' Perdata menyatakan bahwa, semua perkumpulan atau badan terbentuk karena: Pertama, Diadakan atau diakui oleh. kekuasaan umum atau pemerintah. Kedua, Diperbolehkan atau didirikan untuk sesuatu maksud tertentu yang tidak bertentangan dengan undang-undang atau kesusilaan.

Perseroan terbatas sebagai badan hukum mempunyai hak dan kewajiban seperti halnya manusia. Perseroan terbatas mempunyai kedudukan mandiri, artinya kedudukan Perseroan terbatas dalam hukum dipandang berdiri otonom terlepas dari orang perorangan yang berada dalam Perseroan, terbatas, tersebut. ${ }^{4}$ Keberadaan perseroan terbatas tidak tergantung pada keberadaan seseorang atau pihak tertentu, baik sebagai pemegang saham, komisaris, atau direksi, artinya meskipun terjadi pergantian berkali-kali, namun pergantian tersebut tidak mempengaruhi keberadaan perseroan terbatas selaku Pribadi Mandiri di Mata Hukum atau persona standi in judicio. ${ }^{5}$

Perseroan terbatas sebagai badan hukum mandiri mempunyai karakteristik yang

'Hardijan Rusli. 1996. Perseroan Terbatas dan Aspek Hukumnya. Jakarta: Pustaka Sinar. Harapan. HIIm. 17.

2.jbid. HIm. 22.

3/bid.

${ }^{4}$ Rudhi Prasetya. 2001. Kedudukan Mandiri Perseroan Terbatas. Bandung: Citra Aditya Bakti. HIm. 9

${ }^{5}$ Robintan Sulaiman \& Joko Prabowo. 1998. Lebih Jauh tentang Kepailitan, Tanggung Jawab Komisaris, Direksi, dan Pemegang Saham Perusahaan Pailit (Tinjauan Yuridis). Jakarta: Deltacitra Grafindo. HIm. 7. Lihat pula Rudhi Prasetyo. loc. cit. 
ditentukan undang-undang. ${ }^{6}$ Pertama, Perseroan Terbatas merupakan asosiasi modal. Kepustakaan klasik mengklasifikasikan perseroan terbatas sebagai asosiasi modal, , yang mempunyai karakteristik dominan antara lain: ${ }^{7}$ pertanggungajawaban yang timbul semata-mata dibebankan kepada. harta kekayaan yang terhimpun dalam perseroan terbatas; sifat mobilitas atas, hak penyertaan; dan prinsip kepengurusan melalui organ. ${ }^{B}$

Kedua, kekayaan dan utang perseroan terbatas terpisah dari kekayaan dan utang pemegang saham. Ketiga, Tanggung jawab pemegang saham terbatas pada yang disetorkan. Keempat, Adanya pemisahan fungsi antara pemegang saham dan pengurus atau direksi. Kelima, Perseroan Terbatas mempunyai komisaris yang berfungsi sebagai pengawas. Keenam, Kekuasaan tertinggi berada pada Rapat Umum Pemegang Saham.

Perseroan terbatas merupakan wadah yang menghimpun orang-orang yang mengadakan kerja sama dalam, perseroan terbatas, namun segala perbuatan yang dilakukan dalam rangka kerja sama dalam perseroan terbatas tersebut oleh hukum dipandang semata-mata sebagai perbuatan badan hukum. Konsekuensinya, keuntungan yang diperoleh sebagai hak dan harta kekayaan badan hukum tersebut. Sebaliknya, apabila mempunyai utang atau kerugian dianggap menjadi beban perseroan terbatas yang dibayarkan dari harta kekayaan Perseroan Terbatas. ${ }^{9}$

Nindyo Pramono berpendapat perseroan terbatas sebagai badan hukum dihadapkan dengan doktrin atau ajaran umum tentang badan hukum, sehingga mempunyai unsurunsur badan hukum sebagai berikut: ${ }^{10}$ Pertama, Adanya kekayaan terpisah, yang dapat diperoleh dari modal dasar, modal yang ditempatkan dan dari modal yang disetor penuh. Harta kekayaan ini sengaja dibentuk untuk mencapai tujuan perseroan terbatas dalam hubungan hukum di masyarakat. Harta kekayaan ini benar-benar terpisah dari harta kekayaan masing-masing pribadi para pesero. Konsekuensi dipisahnya kekayaan perseroan terbatas sebagai badan hukum dengan harta kekayaan pribadi para pesero adalah: Kreditor pribadi para pesero tidak berhak menuntut harta kekayaan perseroan terbatas; Para pesero pribadi secara pribadi tidak berhak menagih piutang perseroan terbatas terhadap. pihak ketiga; Kompensasi antara utang pribadi dan utang perseroan terbatas tidak diperbolehkan; Hubungan hukum seperti perikatan antara pesero dengan perseroan: terbatas sebagai badan hukum dapat terjadi; dan Apabila terjadi kepailitan, maka para kreditor perseroan terbatas hanya dapat. menuntut harta kekayaan terpisah itu.

${ }^{6}$ Soedjono Dirjosisworo. 1997. Hukum Perusahaan mengenai Bentuk-bentuk Perusahaan (Badan Usaha) di indonesia. Bandung: Mandar Maju. Him. 49.

'Rudhi Prasetyo. op. cit. HIm. 2

8/bid. HIm. 12-27.

9/bid.

${ }^{10}$ Nindyo Pramono. 1997. Sertifikasi Saham PT Go Public dan Hukum Pașar Modal di Indonesia. Bandung: Citra Aditya Bakti. HIm. 24-26. 
Kedua, Adanya tujuan tertentu. Tujuan perseroan terbatas tertuang dalam Anggaran Dasar yang dibuat pàda saat perseroan terbatas didirikan. Cara perseroan terbatas mencapai tujuan ini adalah melengkapi dirinya dengan suatu organ yang disebut direksi. Ketiga, Mempunyai kepentingan sendiri. Kepentingan adalah hak-hak subjektif sebagai akibat dari peristiwa hukum, namun dapat pula berarti suatu keperlưan atau sesuatu yang penting. Kepentingan ini dalam perseroan terbatas tercermin dalam hak-haknya untuk dapat menuntüt dàn mempertahankan terhadaṕ pihak ketiga dalam hủbungan hukumnya.

Keempat, Adanya organisasi yang teratur. Badan hukum adalah suatu konstruksi hukum yang merupakan personifikasi makhluk yuridis, sebagai subjek hukum badan hukum hanya dapat bertindak dengan perantara organnya. Segala perbuatan yang dilakukan badan hukum, diatur dalam Anggaran Dasar dan Anggaran Rumah. Tangga atau peráturanperaturan dan, keputusan-keputusan yang diambil dalam suatu rapat anggota badan hukum tersebut.

Pasal 6 dan Pàsal 7 Undang-Undang Nomor 1 Tahun 1995 tentang Perseroan Terbatas menetapkan bahwa Perseroan Terbatas menjadi badan hukum setelah akta pendiriannya mendapat pengeșahan untuk jangka waktu sesuai yang ditetapkan dalam Anggaran Dasarnya. Penjelasan Pasal 6 Undang-Undang Nomor 1 Tahun 1995 tentang Perseroan Terbatas menyebútkan pada dasarnya jangka waktu berdirinya perseróan terbatas tidak, terbatas, namun apabila jangka waktu tersebut akan ditentukan, maka harus ditegaskán dalam Anggaran Dasar perseroan terbatas.

\section{Direksi sebagai Salah Satu Organ Perseroan . Terbatas}

Berbeda dengan manusia, badan ḥukum perseroan terbatas sebagai subjek hukum, pendukung segala hak dan kewajiban tidak dapat bertindak sendiri. ". Perseroan Terbatas sebagai badan hukum bukan secara alamiah, melainkan ditentukan oleh hukum yang dibuat manusia melalui lembaga yang bërwenang untuk itu.

Supaya berfungsi sebagai badan hukum seperti manusia, perseroan terbatas perlu dilengkapi dengan organ atau alat perlengkapannya. Pasal 1 ayat (2) UndangUndang Nomor 1 Tahun 1995 menyatakan Organ Perseroan adalah Rapat Umum Pemegang Saham, Direksi, dan Komisaris.

Syarat-syarat yuridis bagi direksi perseroan terbatas sebagaimana diatur dalam UndangUndang Nomor 1 Tahun 1995, tentang Perseroan Terbatas meliputi: ${ }^{12}$. Pertama, Direksi harus orang perorangan sebagaimana ditentukan dalam Pasal 79 ayat (3) UndangUndang Nomor 1 Tahun 1995 tentang Perseroan Terbatas. Kedua, Pada prinsipnya suatu Perseroan Terbatas dapat hanya memiliki satu direksi, namun untuk perusahaan tertentu direksi harus lebih dari

"Sanusi Bintang \& Dahlan. 2000. Pokok-pokok Hukum Ekonomi dan Bisnis. Bandung: Citra Aditya Bakti. HIm. 39. 
șatu orang, yaitu perseroan yang, bidang usahanya mengerahkan dana masyarakat, atau menerbitkan surat pengakuan utang, atau terbatas terbuka sébagaimana diatur dalam Pasal 79 ayat (2) Undang Undang Nomor 1 Tahun 1995 tentang Perseroan Terbatas. Ketiga, Cakap berbuat menurut hukum.

Keempat; seseorang dapat diangkat menjadi direktur Perseroan Terbatas apabila orang tersebut secara pribadi tidak pernah dinyatakan pailit oleh pengadilan yang berwenang untuk itu, kecuali pèrnyataan pailit tersebut telah melebihi jangka waktu 5 tahun. Pasal 79 ayat (3) Undang-Undang Nomor 1 Tahun 1995 tentang Perseroan Terbatas mengatur:

"Yang dapat diangkat menjadi Direksi adalah orang perorangan yang mampu -melaksanakan perbuatan hukum dan tidak pernah dinyatakan pailit atau menjadi anggota Direksi atau Komisaris yang dinyatakan bersalah menyebabkan suatu perseroan dinyatakan pailit, atau orang yang pernah dihukum karena melakukan tindak pidana yang merugikan keuangan negara dalam waktu $5 \cdot$ (lima) - tahun sebelum pengangkatan:"

Kelima, Tidak pernah menjadi anggota diréksi yang dinyatakan bersalah, sehingga menyebabkan suatu perseroan terbatas dinyatakan pailit, kecuali keputusan pengadilan ini telah melebihi masa 5 tahun. Penafsiran kesalahan seseorang yang bersalah sehingga menyebabkan Perseroan Terbatas dinyakan pailit ini dapat diartikan secara gramatikal, yaitu Perseroan Terbatas yang dinyatakan dapat perusahaan mana saja, tidak harus Perseroan Terbatas yang dipimpin, yang penting karena perbuatannya tersebut oleh pengadilan dinyatakan bersalah dan berakitbat Perseroan Terbatas dinyatakan pailit. Penafsiran lainnya, yang dinyatakan pailit hanya Perseroan Terbatas tempat seseorang menjadi direksi, dan karena perbuatannya oleh pengadilan dinyatakan bersalah dan berakibat Perseroan Terbatas dinyatakan pailit.

Keenam, Tidak pernah dihukum karena melakukan tindak pidana yang merugikan keuangan negara, kecuali telah 5 tahun atau lebih selesai malaksanakan hukuman tersebut. Ketujuh, Diangkat oleh Rapat Umum Pemegang Saham, menurut tata cara dan syarat-syarat yang diatur oleh Anggaran Dasar Perseroan Terbatas sesuai dengan peraturan perundang-undangan yang berlaku.

\section{Prinsip Fiduciary Duty dalam Undang- Undang Nomor 1 Tahun 1995 tentang Perseroan Terbatas}

Berdasarkan Rapat Umum Pemegang Saham direksi merupakan organ yang mewakili kepentingan Perseroan Terbatas sebagai'subjek hukum mandiri. Pasal 1 angka 4 Undang-Undang Nomor 1 Tahun 1995 tentang Perseroan Terbatas menyatakan:

-Direksi adalah organ perseroan yang bertanggungjawab, penuh atas pengurusan perseroan untuk kepentingan dan tujuan perseroan serta mewákili perseroan baik di dalam maupun di luar pengadilan sesuai dengan ketentuan Anggaran Dasar."

Direksi menjalankan tugas sehari-hari termasuk apabila perseroan terbatas berurusan dengan pengadilan, sehingga wewenang dan fungsi direksi adalah: ${ }^{13}$ 
Pertama, sebagai pengurus. Kedua, sebagai perwakilan. Direksi berfungsi sebagai pengurus secara tegas dinyatakan dalam Pasal 79 ayat (1) Undang-Undang Nomor 1 Tahun 1995 tentang Perseroan Terbatas yang menyatakan: "Kepengurusan perseroan dilakukan oleh Direksi."

Paparan di atas menunjukkan pada prinsipnya fungsi utama direksi suatu perseroan terbatas adalah: ${ }^{14}$ Pertama, fungsi manajemen. Direksi melakukan tugas memimpin perusahaan. Kedua, fungsi representasi. Direksi mewakili perusahaan di dalam maupun di luar pengadilan. Prinsip mewakili perusahaan di luar pengadilan menyebabkan perseroan terbatas sebagai badan hukum terikat dengan transaksi atau kontrak yang dibuat oleh direksi atas nama dan untuk kepentingan perseroan terbatas.

Pasal 130-240 Kitab Undang-Undang Hukum Perdata Belanda mengatur tugas pengurus. ${ }^{15}$ Ketentuan dalam Kitab UndangUndang Hukum Perdata Belanda menentukan bahwa pengurus mempunyai tugas lebih luas daripada hanya urusan pimpinan harian. Namun tidak semua kegiatan pengurus dapat dilakukan sendiri, pengurus diwajibkan megikuti instruksi-instruksi yang ditetapkan oleh Rapat Umum Pemegang Saham, dan tidak boleh melapaui batas-batas wewenang yang digariskan undang-undang dan statutastatuta.

Secara singkat dapat dikatakan bahwa tugas dan wewenang direksi sebagai pengemban kepercayaan yang diberikan oleh pemegang saham (fiduciary duties). Munir Fuady menyatakan prinsip fiduciary duty berlaku bagi direksi dalam menjalankan kedua fungsi direksi di atas. ${ }^{16}$ Fiduciary duty merupakan tugas dari seseorang (trustee) ${ }^{17}$ yang terbit dari suatu hubungan hukum antara trustee dengan pihak lain (beneficiary).$^{18}$ Beneficiary memiliki kepercayaan tinggi kepada pihak trustee. Sebaliknya trustee mempunyai kewajiban tinggi untuk melaksanakan tugas sebaik-baiknya dengan itikad baik (good faith), fair dan penuh tanggung jawab dalam menjalankan tugasnya untuk mengelola aset beneficiary, baik yang timbul dari hubungan hukum atau jabatannya selaku trustee.

Fiduciary duty meliputi: ${ }^{19}$ Pertama, Prinsip kehati-hatian dalam tindakan direksi (duty of skill and care). Kedua, Itikad baik direksi yang semata-mata demi tujuan perseroan terbatas

${ }^{12}$ Munir Fuady. 1999. Hukum Perusahaan dalam Paradigma Hukum Bisnis. Bandung: Citra Aditya Bakti. Him. 80-82.

${ }^{13}$ Robintan Sulaiman \& Joko Prabowo. loc. cit.

${ }^{14}$ Munir Fuady. 2002. Doktrin-doktrin Modern dalam Corporate Law \& Eksistensinya dalam Hukum Indonesia. Bandung: Citra Aditya Bakti. HIm. 32.

${ }^{15}$ W.M. Kleyn. Et. al. 1978. Compedium Hukum Belanda. Leiden: Yayasan Kerjasama Ilmu Hukum Indonesia-Belanda. HIm. 127.

${ }^{16}$ Munir Fuady. "Doktrin..." loc. cit.

"Pihak yang memegang sesuatu dalam kepercayaan untuk kepentingan orang lain.

${ }^{18}$ Pihak yang dipegang kepentingannya.

${ }^{19}$ Robintan Sulaiman \& Joko Prabowo. op. cit. Hlm. 8. 
(duty of loyality). Ketiga, Tidak menggunakan kesempatan pribadi atas kesempatan milik atau bagi perseroan terbatas (no secret profit rule doctrine of corporate opportunity).

Apabila direksi melanggar ketiga asas di atas, maka berlakukan ketentuan dalam Pasal 90 ayat (2) Undang-Undang Nomor 1 Tahun 1995 tentang Perseroan Terbatas. Gugatan atas dasar prinsip fiduciary duty ini dapat melibatkan pribadi pemegang sảham atau pendiri. Pemegang saham maupun pendiri Perseroan Terbatas dapat digugat di muka pengadilan terutama apabila terjadi salah satu keadaan sebagai berikut: ${ }^{20}$ Pertama, Apabila Perseroan Terbatas belum mendapat status badan hukum dari Departemen Kehakiman. Kedua, Perseroan Terbatas yang sudah mendapat pengesahan ternyata tidak menerima, mengambilalih dan tidak menerima (mengukuhkan) transaksi yang dibuat sebelum Perseroan Terbatas tersebut disahkan:

Ketiga, Itikad buruk pemegang saham yang memanfaatkan Perseroan Terbatas untuk kepentingan pribadi, baik dilakukan secara langsung maupun tidak langsung. Keempat, Terjadi tindakan melawan hukum yang dilakukan Perseroan Terbatas yang melibatkan pemegang saham. Kelima, Kekayaan Perseroan Terbatas habis digunakan oleh pemegang saham, sehingga Perseroan Terbatas tidak mampu membayar utang-utangnya kepada pihak ketiga. Keenam, Apabila pemegang saham tunggal! lebih dari enam bulan sejak pemegang saham lainnya melepaskan saham-sahamnya di Perseroan Terbatas.

Hardijan. Rusli berpendapat tanggung jawab direksi antara lain:21 Pertama, Berdasarkan Pasal 30 Undang-Undang Nomor 1 Tahun 1995 tentang Perseroan Terbatas menanggung semua kerugian yang diderita pemegang saham yang beritikad baik akibat pembelian kembali saham oleh Perseroan Terbatas yang menyalahi ketentuan.

Kedua, 'Direksi bertanggungjawab secara tanggung renteng dalam hal: Melakukan perbuatan hukum atas nama perseroan terbatas yang belum didaftar dan diumumkan sebagaimana diatur dalam Pasal 23 UndangUndang Nomor 1 Tahun 1995 tentang Perseroan Terbatas; dan mengakibatkan kepailitan Perseroan Terbatas karena kesalahan atau kelalaian direksi sebagaimana diatur dalam Pasal 90 Undang-Undang Nomor. 1 Tahun 1995 tentang Perseroan Terbatas. Ketiga, Direksi bertanggungjawab secara pribadi terhadap kesalahan atau kelalaian dalam menjalankan Perseroan Terbatas sebagaimana diatur dalam Pasal 85 Undang-Undang Nomor 1 Tahun 1995 tentang Perseroan Terbatas.

\section{Tanggung Jawab Direksi dalam Kepailitan Perseroan Terbatas}

Apabila perseroan terbatas dinyatakan pailit, maka tidak demi hukum pihak direksi harus bertanggung jawab secara pribadi. ${ }^{22}$ Berdasarkan ketentuan dalam Pasal 90 Undang-Undang Nomor 1 Tahun 1995

\footnotetext{
${ }^{20} /$ bid.

${ }^{21}$ Hardjjan Rusli. op. cit. HIm. 124.

${ }^{22}$ Munir Fuady. "Doktrin..." op. cit. HIm. 26.
} 
tentang Perseroan Terbatas, maka direksi dapat diminta untuk bertanggung jawab secara pribadi ketika suatu perseroan terbatas dinyatakan pailit apabila: Pertama, terdapat suatu unsur kesalahan (kesengajaan) atau kelalaian direksi dengan cara pembuktian biasa. Kedua, Apabila aset-aset perseroan terbatas tidak cukup untuk membayar utang dan ongkos-ongkos kepailitan, maka aset pribadi direksi dapat digunakan untuk membayar kekurangan tersebut. Ketiga, Diberlakukan pembuktian terbalik bagi direksi yang dapat membuktikan bahwa pernyataan pailit perseroan terbatas bukan karena kesalahan (kesengajaan) atau kelalaiannya.

Kesalahan direksi yang harus dimintakan pertanggungjawaban berdasarkan doktrin putusan bisnis (business judgement rule) meliputi:23 Pertama, késalahan yang bertentangan dengan prinsip fiduciary duty, termasuk unsur benturan kepentingan (conflict of interest). Kedua, kesalahan yang bertentangan dengan prinsip kehati-hatian (due care), termasuk unsur kelalaian maupun kesengajaan. Ketiga, kesalahan yang bertentangan derigan prinsip putusan yang bijaksana (prudence). Keempat, kesalahan yang bertentangan dengan prinsip tujuan bisnis yang benar (proper purpose). Kelima, kesalahan direksi karena tidak berkompeten. Keenam, kesalahan karena melanggar hukum dan perundang-undangan yang berlaku. Ketujuh, kesalahan karena direksi kurang informasi (ill informed). Kedelapan, kesalahan direksi karena tergesa-gesa dalam mengambil tindakan atau putusan (hasty action).
Kesembilan, kesalahan karena keputusan diambil tanpa investigasi dan pertimbangan rasional.

Unsur kesalahan (kesengajaan) atau kelalaian dalam Undang-Undang Nomor 1 Tahun 1995 tentang Perseroan Terbatas dapat disimpulkan dari ketentuan dalam Pasal 85 ayat (1) dan (2) Undang-Undang Nomor 1 Tahun 1995 tentang Perseroan Terbatas yang menyatakan:

“(1) Setiap anggota direksi wajib dengan itikad baik dan penuh tanggung jawab menjalankan tugasnya untuk kepentingan dan usaha perseroan.

(2) Setiap anggota direksi bertanggung jawab penuh secara pribadi apabila yang bersangkutan bersalah atau lalai menjalankan tugasnya sesuai dengan ketentuan sebagaimana dimaksud dalam ayat (1).

Ketentuan tersebut mensyaratkan bahwa tindakan direksi terhadap perseroan terbatas harus dilakukan dengan memenuhi tiga syarat yuridis: Pertama, itikad baik (good faith); Kedua, penuh tanggung jawab; dan Ketiga, untuk kepentingan serta usaha perseroan terbatas (proper purpose).$^{24}$ Apabila salah satu unsur yuridis tersebut tidak terpenuhi, maka direksi dianggap bersalah (dalam arti kesengajaan) atau setidak-tidaknya dalam kelalaian (negligence) dalam menjalankan tugasnya, sehingga direksi harus bertanggung jawab secara pribadi..$^{25}$

\footnotetext{
23lbid. HIm. 200-201.

${ }^{24} \mathrm{Ibid}$. HIm. 205.

25/bid. HIm. 206.
} 
Literatur hukum perseroan terbatas banyak membahas bahwa terdapat kesalahan direksi yang dapat ditoleransi, antara lain: Pertama, hanya. salah dalam mengambil keputusan (mere error of judgement). Kedua, kesalahan yang jujur (honest error in judgement, honest mistake). Ketiga, kerugian perusahaan karena kesalahan pegawai perusahaan, kecuali jika tidak ada sistem pengawasan yang baik. ${ }^{26}$

\section{Simpulan}

Pasal 90 Undang-Undang Nomor 1 Tahun 1995 tentang Perseroan Terbatas mengatur bahwa direksi dapat diminta untuk bertanggung jawab secara pribadi ketika suatu perseroan terbatas dinyatakan pailit. Namun direksi perseroan terbatas tidak demi hukum harus bertanggung jawab secara pribadi, apabila unsur kesalahan sebagai dasar pertanggungjawaban direksi sebagaimana diatur dalam Pasal 85 ayat (1) dan (2) UndangUndang Nomor 1 Tahun 1995 tentang Perseroan Terbatas tidak terpenuhi. $\square$

\section{Daftar Pustaka}

Bintang, Sanusi \& Dahlan. 2000. Pokok- pokok Hukum Ekonomi dan Bisnis. Bandung: Citra Aditya Bakti.
Dirjosisworo, Soedjono. 1997. Hukum Perusahaan mengenai Bentukbentuk Perusahaan (Badan Usaha) di Indonesia. Bandung: Mandar Maju.

Fuady, Munir. 2002. Doktrin-doktrin Modern dalam Corporate Law \& Eksistensinya dalam Hukum Indonesia. Bandung: Citra Aditya Bakti.

1999. Hukum Perusahaan dalam Paradigma Hukum Bisnis. Bandung: Citra Aditya Bakti.

Kleyn, W.M.. Et. al. 1978. Compedium Hukum Belanda. Leiden: Yayasan Kerjasama IImu Hukum IndonesiaBelanda.

Pramono, Nindyo. 1997. Sertifikasi Saham

PT Go Public dan Hukum Pasar Modal di Indonesia. Bandung: Citra Aditya Bakti.

Prasetya; Rudhi. 2001. Kedudukan Mandiri Perseroan Terbatas. Bandung: Citra Aditya Bakti.

Rusli, Hardijan. 1996. Perseroan Terbatas dan Aspek Hukumnya. Jakarta: Pustaka Sinar Harapan.

Sulaiman, Robintan \& Joko Prabowo.1998. Lebih Jauh tentang Kepailitan, Tanggung Jawab Komisaris, Direksi, dan Pemegang Saham Perusahaan Pailit (Tinjauan Yuridis). Jakarta: Deltacitra Grafindo.

${ }^{26} /$ bid. HIm. 200. 